\section{International Scientific Journal Theoretical \& Applied Science}

p-ISSN: 2308-4944 (print) $\quad$ e-ISSN: 2409-0085 (online)

Year: $2015 \quad$ Issue: $07 \quad$ Volume: 27

Published: $30.07 .2015 \quad \underline{\text { http://T-Science.org }}$

SECTION 34. Tourism.
Dametken Medihanovna Turekulova

Doctor of economic sciences, professor, Kazakh University of Economics, Finance and International trade, Astana, Kazakhstan dametken.t@gmail.com

Lyazzat Kairatovna Mukhambetova

Candidate of economic siences, docent, Kazakh University of Economics, Finance and International trade, Astana, Kazakhstan lmuhambetova@mail.ru

Sholpan Iskakovna Karkinbaeva Master of economics, Senior Lecturer, L.N.Gumilyov Eurasian National University Astana, Kazakhstan sholpanka_k@mail.ru

\title{
TOURISM INDUSTRY OF THE REPUBLIC OF KAZAKHSTAN: CURRENT STATUS AND DEVELOPMENT TRENDS
}

\footnotetext{
Abstract: The article presents the results of a study of the current condition and development trends of the tourism industry in Kazakhstan. The authors' conclusions are based on an analysis of official statistics and complemented with the results of a survey of managers of tourist companies and individual entrepreneurs of Astana. The study identified "problem areas" in the development of tourism, SWOT-analysis of the tourism industry condition of Republic of Kazakhstan.

Key words: tourism industry, outbound tourism, inbound tourism, domestic tourism, accommodations, transportation system, travel agents, tour operators, tourism product, infrastructure.

Language: English

Citation: Turekulova DM, Mukhambetova LK, Karkinbaeva SI (2015) TOURISM INDUSTRY OF THE REPUBLIC OF KAZAKHSTAN: CURRENT STATUS AND DEVELOPMENT TRENDS. ISJ Theoretical \& Applied Science 07 (27): 12-19.

Soi: $\underline{\text { http://s-o-i.org/1.1/TAS-07-27-3 }}$ Doi: crossef http://dx.doi.org/10.15863/TAS.2015.07.27.3
}

Tourism is one of the most dynamic sectors of the economy. The rapid development of tourism in the advanced countries of the world in current decades mainly due to the growth in labor productivity as a result of scientific and technical progress, improving the material well-being and improving their quality of life. Tourist business is stimulated the development of other sectors of the economy: construction, trade, agriculture, consumer goods, communications, etc. According to the World Tourism Organization of the United Nations, in 2012 the number of tourists in the world surpassed 1 billion. The US Travel Association says that every 35 foreign visitors in the country provide for the creation of one workplace [1]. The growth in the number of tourist arrivals is quite influential: over the last 10 years the number of trips abroad in the world has doubled.

Start of independence of Kazakhstan is characterized by the rapid development of international tourism. In connection with the advent of the possibility of free travel abroad during this period develops mainly outbound tourism, which accounts largely advanced inbound and outbound tourism collectively. The period witnessed a significant increase in the number of tourist companies. So, until 1991 tourism in Kazakhstan engaged in 3 companies: Kazakh Republican Council for Tourism and Excursions, Intourist, Sputnik. But in 1994 the country had 589 registered tourist organizations. The share of tourism in GDP in this period was in $1991-0.03 \%$, in $1992-0.09 \%$, in $1993-0.06 \%$, in $1994-0.08 \%$ [2, p. 37].

Extensive development of tourism in the country made it necessary to adopt a number of important pieces of law. However, in the early to mid-90s it was concluded 7 international agreements on cooperation in tourism between Kazakhstan and countries such as Iran, Pakistan, Moldova, Uzbekistan, Kyrgyzstan, Hungary, as well as an agreement on cooperation in the field of tourism with the CIS.

In the late 90 s following events which were held for the formation of the tourism industry in Kazakhstan:

1. Decree of the President of RK "On State Program of the Republic of Kazakhstan" Revival of historical centers of the Silk Road, preservation and 
successive development of the culture of Turkic states, the development of tourism infrastructure "[3]

2. A National Company "Silk RoadKazakhstan"

3. Kazakhstan presented tourist firms at the International Tourism Exchange in Berlin.

4. State management of tourism transferred to the Ministry of Transport, Communications and Tourism of the Republic of Kazakhstan

5. Adoption of the interdepartmental program of activities of embassies of Kazakhstan for development in the tourism [4, p. 35]

6. According to with program were signed international agreements on cooperation in tourism between Kazakhstan and China, Turkey, Bulgaria

7. At later Kazakhstan Tourist Association, was transformed into the Agency for Tourism and Sport of Kazakhstan and the first was presented at the Tourism Fair in London

In 2000-2003, it implements a plan of measures to promote the tourist image of Kazakhstan. So, in order to attract foreign and domestic investment in the industry, resolution was accepted by the Government of the Republic of Kazakhstan "On the organization of the annual International Festival of the Silk Road - Kazakhstan in Almaty city" [5]. In addition, the experiment introduced to simplify visa procedures at the airports of Astana and Almaty. The list of countries included 22 countries. They also signed international agreements on cooperation in the field of tourism between the Government of the Republic of Kazakhstan and Lithuania, Kyrgyzstan, Tajikistan, Uzbekistan, Russia.

The Government of the Republic of Kazakhstan ministries and departments were accepted specific measures aimed to promote the tourism industry and the promotion of entrepreneurship in the field of tourism. In particular, the Guide is designed on a simplified tax regime for individuals engaged in entrepreneurial activities; provided incentives for value-added tax on tourist-excursion services, the right of registration of foreign citizens has been delegated to a variety of hotels. However, the National Bank of Kazakhstan considered the liberation of hotels from the mandatory sale of export proceeds; it was willing to receive foreign currency in cash when working with clients in the five- and four-star hotels. As results of these measures taken in 2004-2006 there was a steady development of the tourism industry in our country, as well as the positive trend of attracting investment in tourism.

However, these measures were not enough for the development of infrastructure and encourage investment in the tourism industry. For example, out of the total investments in the country's infrastructure, for the activities of tourist organizations were attracted only 139 million tenge in 2004, 242 million tenge - in 2005 and 48.3 million tenge - in 2006.

New impetus to the development of the tourist industry has given recognition in the tourism industry as one of the priority sectors of the seven cluster initiatives. As part of the development of the tourist cluster were identified priority areas for the development of tourism. For instance, for business tourism, eco tourism, cultural tourism, educational, and extreme forms of tourism. In this regard, the Resolution of the Government of the Republic of Kazakhstan "On approval of the plans for the creation and development of pilot clusters in priority sectors of the economy", based on which the plan of the creation and development of the pilot cluster "Tourism" in Almaty and Almaty region [6].

At present, the legal basis of tourism in Kazakhstan are: the Law "On tourist activity in the Republic of Kazakhstan" [7] The concept of development of tourism in the Republic of Kazakhstan, the State program of tourism development in the Republic of Kazakhstan for 2007-2011 "State program for accelerated industrialinnovative development the Republic of Kazakhstan for 2010-2014, the Concept of development of the tourism industry of the Republic of Kazakhstan until 2020 [8]. The tourist industry in Kazakhstan on an equal basis with financial instruments is also stimulated through legislation. One popular steps in this direction is the abolition of state licensing of travel agencies, which became operational from the beginning of 2012. In addition, the basic documents of the legal framework in the field of tourism are: the Civil Code of RK Law "About bases of tourist activity in the Republic of Kazakhstan", the Law "On Protection of Consumer Rights", the Law "On Standardization", "On certification of products and services", Resolution of the Government of the Republic of Kazakhstan "On licensing of international tourist activity", Government Resolution "The rules of hotel services in Kazakhstan".

But, despite the measures taken so far, Kazakhstan virtually unknown in the world as a tourist destination. Currently, the share of tourism in the formation of the national income is only $1 \%$. The tourist attraction of the country is estimated as low. For example, according to the World Economic Forum "Travel and Tourism: Competitiveness 2013", Kazakhstan among 139 countries ranked only 88th place [9]. It is also significant that according to the annual ranking of the World Tourism Organization, "World Tourism Barometer" 2010, Kazakhstan was not included in the list of the top five top ten countries. 


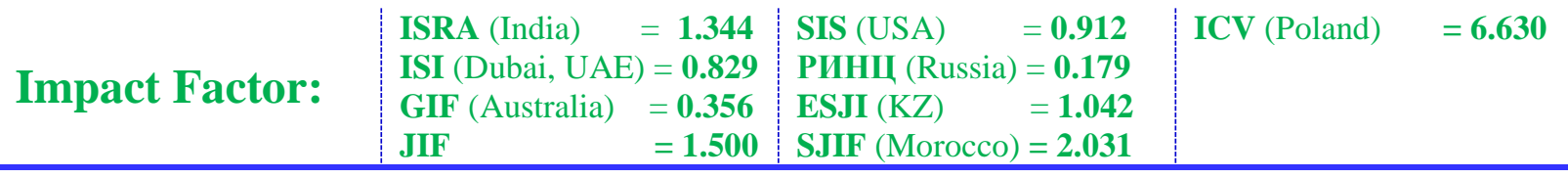

Dynamics of the number of tourists in the Republic of Kazakhstan in 2009-2013.

Table 1

\begin{tabular}{|c|c|c|c|}
\hline Years & Domestic tourism & Outbound tourism & Inbound tourism \\
\hline \multicolumn{5}{|c|}{ the number of people } \\
\hline 2009 & 174940 & 261070 & 37937 \\
\hline 2010 & 122216 & 193951 & 31246 \\
\hline 2011 & 157988 & 261709 & 39640 \\
\hline 2012 & 189502 & 375923 & 36096 \\
\hline 2013 & 186351 & 388108 & 30240 \\
\hline $2013 / 2009$ & +11411 & +127038 & -7697 \\
\hline \multicolumn{5}{|c|}{ change in percent } \\
\hline 2009 & 69,9 & 74,3 & 82,4 \\
\hline 2010 & 129,3 & 135,0 & 126,9 \\
\hline 2011 & 120,0 & 143,6 & 91,1 \\
\hline 2012 & 98,3 & 103,2 & 83,8 \\
\hline 2013 & 106,5 & 148,7 & 79,7 \\
\hline $2013 / 2009$ & & & \\
\hline
\end{tabular}

Nowadays, Kazakhstan is developing steadily only outbound tourism (table 1). But in terms of the development of its own economy outbound tourism can not serve indicators for successful development of the tourist segments. After all, in any country, the level of development of the tourist industry is measured by indicators of inbound and domestic tourism. As according to official statistics, the number of tourists entering the country in 20092013, fell to $20.3 \%$ [10, p. 353]. The major objectives of the visits to Kazakhstan are: business and professional tourism $-54.2 \%$ of the visitors; leisure and recreational tourism - $38.4 \%$; visiting to friends and relatives - 4\%; commercial purposes (shop tours) - $2.1 \%$; other purposes, including the treatment and the pilgrimage $-1.3 \%$ of visitors. This means that the structure of the in our republic soon dominate business and professional trips.

The length of stay of foreign tourists is on average 3 days. This tourist in Kazakhstan a day spends about 75-85 US dollars. Whereas according to the World Tourism Organization, overseas tourist spends approximately 250-350 US dollars per day [11]. It is clear that the country will not be able to increase tourist attraction, while the majority of visitors will visit it on working visits and not for holidays.

\section{The dynamics of the tourism industry of Kazakhstan in 2009-2013.}

Table 2

\begin{tabular}{|l|c|c|c|c|c|c|}
\hline \multicolumn{1}{|c|}{ Indicators } & \multicolumn{5}{|c|}{ Year } & $\begin{array}{c}\text { Change } \\
\text { from 2013 } \\
\text { to 2009, } \%\end{array}$ \\
\cline { 2 - 7 } & 2009 & 2010 & 2011 & 2012 & 2013 & 168,0 \\
\hline $\begin{array}{l}\text { The number of served in } \\
\text { the placements, people }\end{array}$ & 1801087 & 1544506 & 2548868 & 2845832 & 3026227 & 127,6 \\
\hline $\begin{array}{l}\text { The number of serviced } \\
\text { by tourist firms, people }\end{array}$ & 473947 & 347413 & 459337 & 601521 & 604699 & 114,4 \\
\hline $\begin{array}{l}\text { Scope of works } \\
\text { (services), thousand } \\
\text { tenge }\end{array}$ & 15439066 & 11424444 & 14730718 & 15142092 & 17674698 & 113,3 \\
\hline $\begin{array}{l}\text { The number of } \\
\text { accommodation } \\
\text { facilities, units }\end{array}$ & 528 & 562 & 677 & 692 & 598 & \\
\hline
\end{tabular}

In accordance with table 2, all indicators of the tourist industry is experiencing steady growth. At the same time the highest growth rates are characteristic of the number of served tourists in places of accommodation. In 2009, in one place for accommodation in the middle serviced 3411 people, in 2013 the figure was 5060 people. Despite the increase in occupancy placements usually filled only one-fifth of hotel rooms. Low hotel occupancy is related primarily to higher prices for accommodation, which in turn makes the unpopular Kazakhstan in the eyes of foreign tourists. 
The whole country tourist firms served in 2009 473947 people. By the beginning of 2014 their number increased by 130752 people, which is an increase of $27.6 \%$. In this regard, an increase in the volume of work performed. The greatest volume of works and services recorded in 2013, and the lowest - in 2010. At the same time, increasing revenues from the sale of tourist firms vouchers, but especially a sharp rise in income accounts for 2012 and 2013. Overall, in 2009-2013, growth in revenues from the sale of tourist firms permits was $61.2 \%$. To some extent this is due to the cost of permits. Thus, the rising cost of permits in 2010 (61 thousand tenge) compared to the previous year by $57 \%$ helped reduce the activity of the citizens of Kazakhstan in the domestic and foreign tourism. A decrease in the average cost of travel in 2011 (46.22 thousand tenge) led to an increase in tourist activity in all directions.

The main suppliers of tourist services in our country are tourist firms and individual entrepreneurs who have a license for tourist activity. They are collaborate with more than 80 countries in the world.

Companies and individual entrepreneurs engaged in tourism activities, units.

Table 3

\begin{tabular}{|l|c|c|c|c|c|c|c|}
\hline \multicolumn{2}{|c|}{ Indicators } & \multicolumn{3}{c|}{ Year } & \multicolumn{2}{c|}{$\begin{array}{c}\text { Changes from } \\
2013 \\
\text { to } 2009\end{array}$} \\
\cline { 2 - 8 } & 2009 & 2010 & 2011 & 2012 & 2013 & $(+,-)$ & $\%$ \\
\hline Number of tourist firms & 1163 & 1203 & 1252 & 1567 & 1720 & 557 & 147,8 \\
\hline $\begin{array}{l}\text { The number of private entrepreneurs } \\
\text { in the tourism sector }\end{array}$ & 64 & 73 & 98 & 117 & 136 & 72 & $\begin{array}{c}\text { more } \\
\text { than } \\
2.1 \text { time }\end{array}$ \\
\hline $\begin{array}{l}\text { The number of individual } \\
\text { entrepreneurs engaged in tourist } \\
\text { accommodation }\end{array}$ & 621 & 664 & 787 & 936 & 1106 & 485 & 178,1 \\
\hline
\end{tabular}

According to table 3, for the period from 2009 to 2013 the number of tourist agencies in the country increased by 557 units or $47.8 \%$. While the number of individual entrepreneurs engaged in tourism activities increased by more than 2 times. According to we can see wich tourism activity is becoming more attractive for small businesses. But most of the entrepreneurs engaged in tourist accommodation. In recent years their number has increased by $78.1 \%$. The share of individual entrepreneurs engaged in tourist accommodation, the total number of entrepreneurs in 2009-2013 ranged from 89\% - 91\%.

According to experts, the effective development of tourism in Kazakhstan is largely hampered by a lack of state regulation of tourism development and underdeveloped infrastructure. According to Figure 1, the first level of infrastructure - tourism management - represented by institutions for the management of tourism sector of the economy. The first is the republican legislative and executive management bodies: the Parliament and the Government of the Republic of Kazakhstan. Despite the fact that the Parliament, which is composed of the Senate and the Majilis, no tourism-oriented structural units, Parliament engaged in legislative activity in this area.

Committee of Tourism Industry of the Ministry of Industry and New Technologies defines the strategic directions of development of tourism in Kazakhstan. He manages 14 regional governments, which have the structure of tourism, physical culture and sports. Information: independent regional tourism management operate in Akmola, Almaty, Mangistau and South Kazakhstan regions, as well as in the city of Almaty. Independent departments of tourism development in the management of businesses operate in five regions - Aktobe, Atyrau, Zhambyl, Kyzylorda and North Kazakhstan. Office of Tourism of Pavlodar region in 2014 was transformed into Department of Tourism Regional Office business. However, still not resolved the issue of establishing independent departments for the development of tourism in the respective offices of the West Kazakhstan, Kostanay and Karaganda regions where tourism issues by specialists of related departments. In particular, in the Kostanai region tourism functions are removed from the control of physical culture and sports, and to transfer the management of business without releasing regular units of Tourism. In addition, the tourism authorities are absent at the district level or at the level of cities of regional subordination, which can be considered as a drawback of the existing system of tourism management.

We mean, also we need to help for strengthening of the role of social tourism associations. Because these include, particular, the Tourist Board of the Government of the Republic of Kazakhstan, which is an advisory body in our country [12]. 


\begin{tabular}{|c|c|c|c|c|c|c|}
\hline Impact Factor: & $\begin{array}{l}\text { ISRA (India) } \\
\text { ISI (Dubai, UAE } \\
\text { GIF (Australia) } \\
\text { JIF }\end{array}$ & $\begin{array}{l}=1.344 \\
=0.829 \\
=0.356 \\
=1.500\end{array}$ & $\begin{array}{l}\text { SIS (USA) } \\
\text { PИHЦ (Russia) } \\
\text { ESJI (KZ) } \\
\text { SJIF (Morocco) }\end{array}$ & $\begin{array}{l}=0.912 \\
=0.179 \\
=1.042 \\
=2.031\end{array}$ & ICV (Poland) & $=6.630$ \\
\hline
\end{tabular}

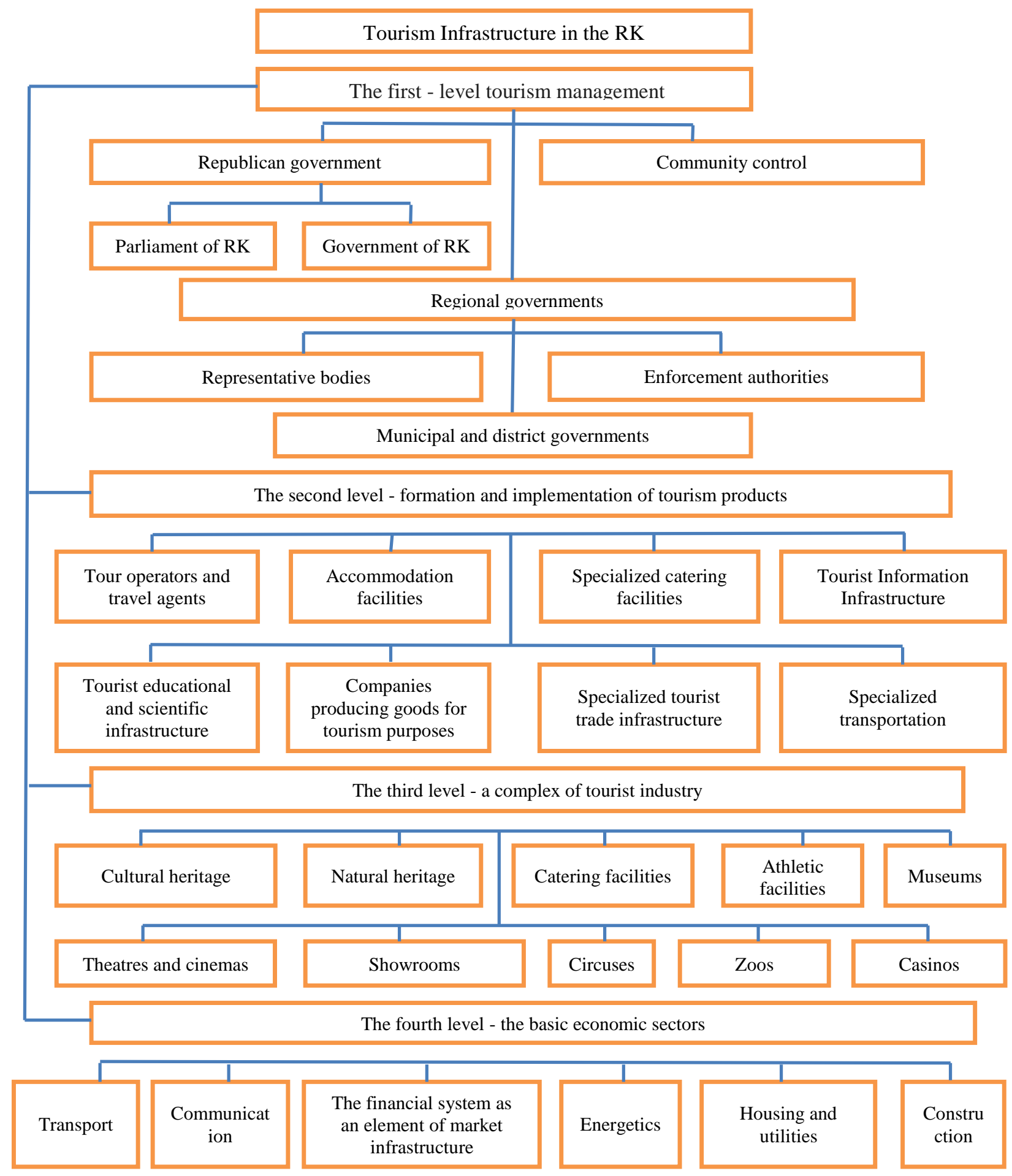

Figure 1 - Tourism infrastructure in the Republic of Kazakhstan.

In additional, an active role in the development of tourism plays Kazakhstan Tourist Association, established in 1999. It is a non-profit and nongovernmental organization, which consists of: Kazakhstan Association of Hotels and Restaurants, tourist, insurance, airlines, universities and the media. Representatives of the Association are located in the cities of Almaty, Astana, Aktau, UstKamenogorsk, Shymkent, Moscow and Tashkent.

The second level of tourism infrastructure of Kazakhstan - the company that developed and implemented a tourist product. First of all, the tour operators and travel agents. The number of tour operators in Kazakhstan is not known because there is the national register of tour operators, although this

ISPC Intelligent technologies, 
type of business activities subject to licensing. In respect of travel agents has changed for the better. So, in early 2012 entered into force on additions and amendments to the Law "On tourist activity", according to which canceled the licensing of travel agencies [13]. In the same year the Kazakhstan Tourist Association decided to create a unified register of travel agents of RK. To the information: single register of travel agents is an electronic database of enterprises and individual entrepreneurs engaged in travel agency activities. In the case of a contract of compulsory liability insurance travel agent is required to provide information to the Committee of the tourism industry of the Ministry of Industry and New Technologies of the persons carrying out tourist activities.

The formation and implementation of the tourism product of considerable importance is the tourist educational and scientific infrastructure of Kazakhstan. This infrastructure is represented by the 28th universities that are training managers of tourism. So, each year the country produced about 900 specialists with higher and about 400 specialists with secondary vocational education, which is totally inadequate [14].

However, the essential role played by specialized tourist information infrastructure, which nowadays is in its infancy. In particular, there is no tourist registry and cadastre. So far it is not known exactly how many monuments in the country's historic cultural and natural heritage sites or tourist destination. If there is no such official document, travel companies and individual tourists to learn about it the more impossible. The existing register of tourist routes and trails conducted formally and can not replace a tourist registry and cadastre [15]. However, the information vacuum on their own trying to make up for the Kazakhstan Tourist Association, which was launched 2 projects. So, since 2005, it operates a so-called eco-tourism center - information resource center that collects offers of travel agencies, separate guest houses. The second project, launched in 2012, is an information center in Almaty, the visitor center, which provides information about the tour is that you can visit in the city.

At the third level of tourism infrastructure are the objects of cultural and natural heritage, which is rich in the republic. The UNESCO World Heritage List includes three Kazakh object that is $0.3 \%$ of the total. This 2 properties are included in the list of cultural criteria, and one of them is recognized as a masterpiece of human genius. And the object 1 is enabled by natural criteria. These objects include the Mausoleum of Khoja Ahmed Yasawi, Petroglyphs within the Archaeological Landscape of Tamgaly, Saryarka, Naurzum and Korgalzhyn reserve. At the same time, another 12 facilities should be included in addition to the World Heritage List [16, p. 50].

The fourth level of tourism infrastructure is a basic sectors of the economy, among which the most important is the transport system.

The dynamics of the carriage of passengers by mode of transport, mln. people.

Table 4

\begin{tabular}{|c|c|c|c|c|c|c|}
\hline \multirow[t]{2}{*}{ Types of transport } & \multicolumn{5}{|c|}{ Years } & \multirow{2}{*}{$\begin{array}{l}\text { Changes } \\
\text { from } 2013 \\
\text { to } 2009, \%\end{array}$} \\
\hline & 2009 & 2010 & 2011 & 2012 & 2013 & \\
\hline \multicolumn{7}{|l|}{ Intercity } \\
\hline \multicolumn{7}{|l|}{ including: } \\
\hline - bus & 12,8 & 12,3 & 15,5 & 17,8 & 18,7 & 146,1 \\
\hline - rail & 10,9 & 12,1 & 13,1 & 16,4 & 20,1 & 184,4 \\
\hline - air & 1,8 & 2,2 & 2,6 & 2,8 & 3,0 & 166,7 \\
\hline \multicolumn{7}{|l|}{ International } \\
\hline \multicolumn{7}{|l|}{ including: } \\
\hline - bus & 1,1 & 1,1 & 1,1 & 1,4 & 1,5 & 136,4 \\
\hline - rail & 4,5 & 4,1 & 3,7 & 3,9 & 4,3 & 95,6 \\
\hline - air & 1,0 & 1,2 & 1,5 & 1,7 & 2,0 & More than 2 \\
\hline
\end{tabular}

According to the data of Table 4, transportation of tourists in the country by air, road and rail. The vast majority of tourist companies provides both the citizens of Kazakhstan sending and reception of foreign citizens, as well as domestic tourism. In intrarepublican message priority it is for bus and train connections $[17$, p. 16]. On international routes, the main type of tourist movement is rail transport. In recent years, under international post this kind of transport carried more than 4 million people. However, in terms of traffic growth in the first place there is air communication.

It should be noted that along with the domestic airlines engaged in international transport carriers in other countries. Republic has air links with many countries of the world, and therefore for foreign airlines operating between Europe and Southeast Asia, transit air routes in Kazakhstan are extremely 
profitable. We can say that the air transport of the republic is the only component of infrastructure in tourism industry, which is at the proper level. The main carrier is the "Air-Kazakhstan". Perhaps this is why foreign tourists often use the services of air transport. Their number is $94.7 \%$ of the total number of foreign tourists. Rail prefer to use $3.3 \%$ of tourists traveling by bus and about $0.4 \%$ of the tourists. The first place in tourism industry taken is the air transport $(74.4 \%)$, followed by - coaches $(14.8 \%)$, in third place - railway transport $(9.9 \%)$ and in last place - other land agents $(0.9 \%)[18$, p. 29$]$.

Table 5

SWOT-analysis of the tourism industry condition of Republic of Kazakhstan.

\begin{tabular}{|c|c|}
\hline Strengths & Weakness \\
\hline 1. Rich natural and cultural heritage of the Republic & 1. Low share of tourism in gross domestic product \\
\hline $\begin{array}{l}\text { 2. Strengthening the role of social tourism } \\
\text { associations }\end{array}$ & $\begin{array}{l}\text { 2. A significant predominance in the structure of } \\
\text { tourist activity of outbound tourism }\end{array}$ \\
\hline $\begin{array}{l}\text { 3. Revitalization of the Kazakhstan Tourist } \\
\text { Association }\end{array}$ & $\begin{array}{l}\text { 3. Inconsistency most placements with international } \\
\text { standards on price, service and other factors }\end{array}$ \\
\hline $\begin{array}{l}\text { 4. Proclamation of the tourist industry as a priority } \\
\text { direction of the economy }\end{array}$ & $\begin{array}{l}\text { 4. The moral and physical deterioration of tourism } \\
\text { infrastructure }\end{array}$ \\
\hline $\begin{array}{l}\text { 5. Activation of the government to reform the } \\
\text { transport infrastructure }\end{array}$ & $\begin{array}{l}\text { 5. Poor quality of services of tourist companies and } \\
\text { individual entrepreneurs }\end{array}$ \\
\hline 6. In general, the normative-legal base of tourism & $\begin{array}{l}\text { 6. The low demand for graduates due to lack of skills } \\
\text { and knowledge in specific specializations }\end{array}$ \\
\hline 7. The rich tourist and recreational potential & $\begin{array}{l}\text { 7. Underdevelopment specialist } \\
\text { Tourism information infrastructure }\end{array}$ \\
\hline 8. Have enough employment potential of the republic & $\begin{array}{l}\text { 8. The low competitiveness of domestic carriers due } \\
\text { to the lack of development } \\
\text { service and unreliability }\end{array}$ \\
\hline & $\begin{array}{l}\text { 9. Lack of state support for the development of } \\
\text { domestic tourism }\end{array}$ \\
\hline Opportunities & Threats \\
\hline $\begin{array}{l}\text { 1. Increase of employment, which is especially } \\
\text { important for the development of regions }\end{array}$ & $\begin{array}{l}\text { 1. Inadequate condition of roads of national and } \\
\text { regional importance }\end{array}$ \\
\hline 2. The stable growth of the country's income & 2. Lack of tourist Registry and Cadastre \\
\hline $\begin{array}{l}\text { 3. Improving the institutional infrastructure through } \\
\text { the establishment of regional offices of tourism }\end{array}$ & $\begin{array}{l}\text { 3. Almost no modern and comfortable buses, which } \\
\text { does not allow to maintain a high level of tourist } \\
\text { services }\end{array}$ \\
\hline $\begin{array}{l}\text { 4. Creating a modern multifunctional tourist centers of } \\
\text { world-class }\end{array}$ & $\begin{array}{l}\text { 4. Low volume of attracted investments in tourism } \\
\text { and unstable rates of growth }\end{array}$ \\
\hline $\begin{array}{l}\text { 5. The creation and development of public-private } \\
\text { partnership in the field of tourism }\end{array}$ & $\begin{array}{l}\text { 5. The non-recognition of tourist activity as a } \\
\text { priority by the local authorities }\end{array}$ \\
\hline 6. The revival of investment activity in the regions & $\begin{array}{l}\text { 6. Political and administrative aspects of the } \\
\text { development of the tourism industry }\end{array}$ \\
\hline $\begin{array}{l}\text { 7. Imaginary reality of Kazakhstan in the field of } \\
\text { tourism }\end{array}$ & $\begin{array}{l}\text { 7. The lack of attractiveness of tourism industry of } \\
\text { Kazakhstan for foreign investment }\end{array}$ \\
\hline $\begin{array}{l}\text { 8. Implementation of the Concept of development of } \\
\text { tourism industry of Kazakhstan till } 2020\end{array}$ & $\begin{array}{l}\text { 8. The lack of a common information base for } \\
\text { attracting potential investors }\end{array}$ \\
\hline $\begin{array}{l}\text { 9. The use of international experience in the } \\
\text { development of the tourism industry }\end{array}$ & $\begin{array}{l}\text { 9. Lack of development tools supporting the } \\
\text { effective management of investments (project } \\
\text { financing, tax incentives, unsecured long-term } \\
\text { financing) }\end{array}$ \\
\hline
\end{tabular}

Analysis of the current situation shows that there is a whole set of problems, because of which the tourist industry in Kazakhstan may reach a stable level of development. These problems have repeatedly voiced by representatives of the government and various experts. The main obstacles to the development of the tourism industry in
Kazakhstan are the following: low volume of attracted investments in tourism and unstable rates of their growth; the lack of attractiveness of tourism industry of Kazakhstan for foreign investment; multilayered nature of the unsatisfactory state of tourism infrastructure; the system of professional training in the tourism and service; political and administrative 
aspects of the development of the tourism industry; insufficiently favorable business climate; the nonrecognition of tourist activity as a priority by the local government; insufficient financial resources allocated for the promotion of domestic tourism; poor quality of services provided.

The data in table 5 demonstrate that the transformation of tourism into a major independent sector of the economy of Kazakhstan is possible if we will be make efficient infrastructure. Also, the most serious obstacles to the development of tourism is the problem of training, improvement of the system of state support, and weak positioning in the international market. The solution of these problems in the short term, will allow Kazakhstan to develop tourism more dynamic and to enter the international market with its unique product.

\section{References:}

1. (2015) In the world the first time counted more than a billion tourists // Available: www.zn.ua/WORLD/v-mire-vpervyenaschitali-bolee-milliarda-turistov.html (Accessed: 20.06.2015).

2. Zorin IV, Kvartalnov VA (2000) Tourism Encyclopedia: A Guide - Almaty KarjaKarazhat, 2000.- 368 p.

3. (1998) Presidential Decree. On the State Program of the Republic of Kazakhstan, Revival of historical centers of the Silk Road, preservation and successive development of the culture of Turkic states, the development of tourism infrastructure: adopted on February 27, 1998.

4. Duysen GM (2002) Bases of formation and development of the tourism industry in Kazakhstan - Almaty: «LEM», 2002. - 127 p.

5. (2000) Government Resolution. On the organization of the annual International Festival of the Silk Road - Kazakhstan in Almaty: adopted on 27 November 2000.

6. (2005) Government Decision. On approval of the plans for the creation and development of pilot clusters in priority sectors: adopted on 25 June 2005.

7. (2001) The Republic of Kazakhstan. Law of the Republic of Kazakhstan. On tourist activity in the Republic of Kazakhstan: adopted 13 June 2001.

8. (2014) The concept of development of the tourism industry of the Republic of Kazakhstan till 2020. Resolution of the Government of the Republic of Kazakhstan: adopted on March 19, 2014, № 508 .

9. (2013) The Travel \& Tourism Competitiveness Report 2013 // 2013 World Economic Forum // Available: www.weforum.org/ttcr (Accessed: 20.06.2015).
10. (2014) Statistical Yearbook of "Kazakhstan 2013" / ed. A.A.Smailov - Astana, 2014. - 484 p.

11. (2015) $90 \%$ of tourists visiting Kazakhstan only once // Available: www.oskemen.info/318090-turistov-poseshhayut-kazaxstan-tolko-odinraz.html (Accessed: 20.06.2015).

12. (2014) Resolution of the Government of Kazakhstan. On Education Tourism Board (as amended): adopted on September 4, 2014, № 1631.

13. (2014) The Republic of Kazakhstan. Law of the Republic of Kazakhstan. On tourist activity in the Republic of Kazakhstan (as amended): adopted on 13 January 2014.

14. (2015) The personnel problem in the development of tourist cluster of Kazakhstan // Available: www.arbir.ru/articles/a_2925.htm (Accessed: 20.06.2015).

15. (2015) Maintenance of the State Registry of tourist routes and trails // Available: www.kit.gov.kz/index.php/ru/razvitieinfrastruktury (Accessed: 20.06.2015).

16. Pilyavskii VP, Tahtaeva RS (2013) The tourism industry in East Kazakhstan: Opportunities and Problems of Development // Journal of the National Academy of Tourism, 2013, № 2 (26). - pp. 49-52.

17. (2014) Tourism in Kazakhstan. Statistical Yearbook / ed. A.A.Smailov - Astana, 2014. $133 \mathrm{p}$.

18. Bondarenko $\mathrm{T}$ (2014) The main directions of development of tourism in the Republic of Kazakhstan // Materiali III mizhnarodnoï NAUKOVO-praktichnoï konferentsiï "Industriya gostinnosti in kraïnah Evropi." Simferopol: ViTroPrint, 2014. - pp. 28-31. 